\title{
Accumulation and migration of elements-pollutants in "soil-plant" system within urban territory
}

\author{
Tatiana A. Mikhailova, Olga V. Shergina, Olga V. Kalugina
}

Siberian Institute of Plant Physiology and Biochemistry, Siberian Branch of the Russian Academy Sciences, Irkutsk, Russia; mikh@sifibr.irk.ru

Received 12 March 2013; revised 14 April 2013; accepted 22 April 2013

Copyright (C) 2013 Tatiana A. Mikhailova et al. This is an open access article distributed under the Creative Commons Attribution License, which permits unrestricted use, distribution, and reproduction in any medium, provided the original work is properly cited.

\section{ABSTRACT}

In the urbanized territory (the Irkutsk city), the content of sulfur and heavy metals (lead, cadmium, copper, zinc) in soil profile horizons and leaves (needles) arboreal plants were studied. High accumulation of polluting elements in pine and larch needles, birch and poplar leaves, as well as in all genetic horizons of the city soils was shown. There were revealed elements disbalance in city trees assimilation organs showing in the increase of the polluting elements quota with the parallel decrease of the quota of nitrogen, phosphorus, calcium, magnesium, potassium, manganese. Pollutants concentration in trees needles (leaves) was shown to be closely related to their content in soil horizons. The results speak in favor of high migration ability of polluting elements in soil profile and about possibility their entrance in trees root system and further to assimilation organs from all city soils horizons. It can be concluded that data on accumulation and migration of polluting elements in soils and arboreal trees assimilation organs contribute to adequate assessment of technogenic load on urban ecosystems.

Keywords: Urban Ecosystem; Air Pollution; Arboreal Plants; Soil Genetic Profile

\section{INTRODUCTION}

Current urbanization enhancement makes urgent studies of environmental status of cities, particularly their components with key environment-forming and environment-protective functions, such as vegetation and soil cover. Present-day cities are characterized by high intensity and large scale of technogenic chemical pollution, so the cities may be regarded as technogenic biogeochemi- cal provinces $[1,2]$. The above necessitates research of the processes of biogeochemical migration of polluting substances in "soil-plant" system for evaluation of environment quality in the urbanized territories. The results of such studies allow not only to reveal and forecast negative changes in urban ecosystems, but to develop recommendations to optimize plant and soil cover status in the cities.

Permanent intense negative factors in urban ecosystems are polluted by technogenic waste and high recreational load; it shows to them that soils and plants primarily need to adapt. Analysis of the data of our multi-annual research proves that soil as urban ecosystem component is characterized by higher resistance to anthropogenic load and better ability to neutralize polluting agents, than vegetation. Arboreal plants, particularly conifers, are a component, which is more vulnerable to anthropogenic factors impact. Complex studies of urban ecosystems consider both components - soil cover and arboreal vegetation - as highly informative indicators of accumulation and migration of chemical elements arriving with the technogenic waste and emissions in the urban ecosystem [3]. Therefore, interrelated investigation of soils and arboreal plants contributes to the assessment of the technogenic pressure intensity and degree of disturbance of ecological status in the city.

The aim of the present work is to study accumulation and migration of elements-pollutants (sulfur, lead, cadmium, copper, zinc) within the system "soil-arboreal plants" in urbanized territory.

\section{MATERIAL AND METHODS}

\subsection{Study Area}

The studies were performed in 2007-2011 in the territory of the Irkutsk city — an administrative and industrial center of Eastern Siberia (Russia). The city is included in the list of the Russian cities with the highest air pollution 
level [4]. There are over 180 industrial plants and over 300 boiler houses in the city. At the moment the primary and most dangerous pollution source for the city atmosphere is automobile transport, which produces for about $60 \%$ of the total amount of emissions. Industrial and automobile emissions release to the city atmosphere up to 140 thousand tons of toxic aerosols and acid components. Permissible concentrations of 46 harmful substances have been exceeded in the city atmospheric air [5]. Thus, the level of soluble forms of heavy metals was exceeded to 4 - 10 time, of sulfur dioxide - 6 time [6,7].

High level of air pollution within the city is also due to complex orographic and climatic peculiarities, which prevent self-purification of the near-surface atmospheric stratum. Increased air humidity and lack of wind access to the closed hollow territory of Irkutsk result in the formation of sectors of high concentrations of pollutants, often with summation and synergism effect. High level of pollution of Irkutsk air basin, in its turn, causes significant level of vegetation and soil cover pollution.

Irkutsk is located in the zone of subtaiga pine forests. Soil cover here is represented by sandy and loamy grey forest soils. To study processes of migration of elementspollutants in the system "soil-plant", park and forest-park areas of the city were selected. Altogether there were studied 16 key plots (parks and forest-parks) situated in different districts of the city-central, north-western, eastern, and in the outskirts. Background plots were selected at a significant distance from the city (more than $100 \mathrm{~km}$ ) in natural forests with identical soil genesis.

\subsection{Objects of the Research and Parameters Analyzed}

Objects of the research were city grey forest soils and arboreal species: Scots pine (Pinus sylvestris L.), Siberian larch (Larix sibirica Ledeb.), poplar (Populus sp.), birch (Betula pendula Roth). Needles (leaves) samples for analysis on the content of chemical elements were taken at each key plot, a number of morphostructural parameters of tree crowns was also studied. Soils were investigated by both the method of sample selection along genetic profile down to the depth of $1.5 \mathrm{~m}$, and by square-envelope method of averaged samples from top strata $(0-20 \mathrm{~cm})$ of the soil cover. All field and laboratory research of soils and trees were carried out in accordance with the international methodology of the ICP Forests [8].

In the laboratory plant samples were analyzed for content of total sulfur, and soil samples-for concentration of mobile sulfur forms by method of sulfate precipitation by barium chloride. Overall and soluble forms of heavy metals in plant and soil samples were measured by atomic absorption with using AAS Vario-6 company
"ANALITIK JENA". Determination of the heavy metals contents in plant samples and organic litter was made after incineration of the material with hydrochloric acid. In soil samples measurement the content of heavy metals mobile forms was performed in the extracts $1 \mathrm{M} \mathrm{HCl}$. Determination cation exchange capacity (CEC) in soil samples was made using $1 \mathrm{M} \mathrm{CH}_{3} \mathrm{COONH}_{4}$. In addition, plant samples were analyzed for content of phosphorus, potassium, magnesium, manganese.

The data were processed statistically using standard procedures including correlation and regression analyses. Data processing was carried out using Microsoft Excel, Mathcad 12 software.

\section{RESULTS}

The results acquired prove significant accumulation of heavy metals and sulfur in assimilation organs of arboreal plants in the city (Figure 1). Thus, lead concentration in the needles of pine trees growing in the city center exceeds background values by 15 times, concentration of cadmium - by 6 times, that of copper and sulfur - by 3 times. In the city territories located near heat power plants and a number of industrial enterprises very high concentrations of heavy metals and sulfur in trees assimilating phytomass are identified. For example, content of lead exceeds background level in pine needles and birch leaves by 25 times, in larch needles - by 20 times, in poplar leaves - by 15 times. On the outskirts low level

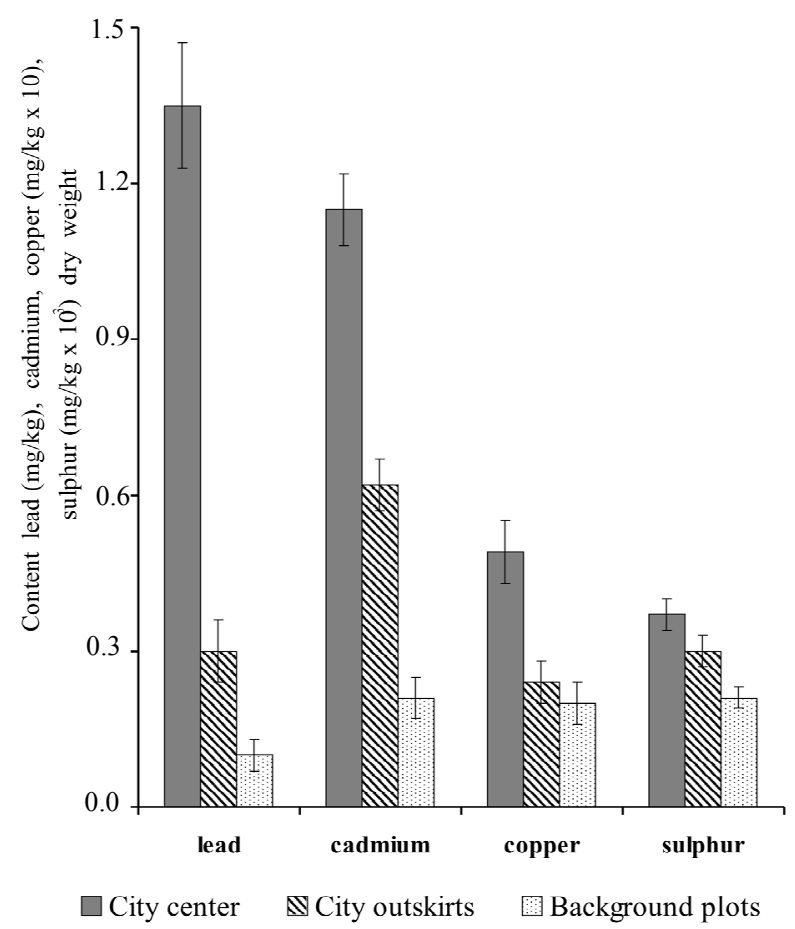

Figure 1. Content of elements-pollutants in pine needles in city and background territories. 
of polluting elements accumulation is registered in trees needles and leaves.

The impact of polluting elements on the city trees is one of the factors worsening of their morphostructural parameters. This is confirmed by correlation links revealed between tree crowns characteristics and lead content in trees needles (Table 1). Reliable correlation was also revealed between tree crowns characteristics and content of sulfur, cadmium, copper. These parameters in the background territories show no reliable correlations.

Under technogenic air pollution trees needles and leaves suffer disturbance in elements proportion [9]. We have shown the increase quota of sulfur, lead, cadmium, copper, and the parallel decrease quota of nitrogen, phosphorus, calcium, magnesium, manganese in city tree assimilating organs. Correspondingly, alteration in the elements proportion has been significant. It is demonstrated for lead and sulfur as an example (Table 2). These data indirectly prove higher toxicity of lead for plant organism.

The study of the city soils was carried out along the whole genetic profile comprising the totality of the following horizons: O-Ad-A-AB-B (BE)-Bt, f-BC-C [10]. Each of these horizons is characterized by certain morphological signs: $\mathrm{O}$-low thickness $(1-2 \mathrm{~cm})$ organic litter of medium decomposition degree; Ad-humusaccumulative horizon 5 - $12 \mathrm{~cm}$ thick; A-humus-eluvial horizon $(5-15 \mathrm{~cm})$; AB - transfer eluvial-illuvial horizon (10 - $20 \mathrm{~cm})$; B(BE)-illuvial horizon $(10-40 \mathrm{~cm})$; $\mathrm{Bt}, \mathrm{f}$-illuvial texture horizon $(15-40 \mathrm{~cm})$; BC-transfer horizon from illuvial to soil-formed rock $(15-50 \mathrm{~cm})$; $\mathrm{C}$ - soil-formed horizon $(20-70 \mathrm{~cm})$.

The results acquired prove an intense change in the content of mobile forms of sulfur, lead, cadmium, copper, zinc in vertical direction of the city soils genetic profile. For example, the level of lead in soil horizons (from Ad to the depth to C) may exceed background values by 2 to 20 times, cadmium - by 2 to 10 times, copper-by 1.5 to

Table 1. Coefficients of correlation between morphostructural parameters of trees crowns and lead content in trees needles $(P$ $<0.05, n=32$ ).

\begin{tabular}{ccc}
\hline Parameters & Pine & Larch \\
\hline Shoot $^{*}$ needles mass & -0.69 & -0.65 \\
Mass of 100 needles & -0.66 & -0.71 \\
Number of needles on the shoot & -0.72 & -0.63 \\
Shoot length & -0.78 & -0.53 \\
Needles length & -0.72 & -0.75 \\
Crown defoliation level & +0.74 & +0.64 \\
Needles discoloration level & +0.69 & +0.71 \\
\hline
\end{tabular}

*2-year-old shoots were considered.
Table 2. Alteration in the elements proportion in the needles and leaves of trees in city and background territories.

\begin{tabular}{ccccccc}
\hline \multirow{2}{*}{$\begin{array}{c}\text { Elements } \\
\text { proportion }\end{array}$} & $\begin{array}{c}\text { City } \\
\text { center }\end{array}$ & $\begin{array}{c}\text { City } \\
\text { outskirts }\end{array}$ & $\begin{array}{c}\text { Background } \\
\text { plots }\end{array}$ & $\begin{array}{c}\text { City } \\
\text { center }\end{array}$ & $\begin{array}{c}\text { City } \\
\text { outskirts }\end{array}$ & $\begin{array}{c}\text { Background } \\
\text { plots }\end{array}$ \\
\hline \multicolumn{5}{c}{ Lead } \\
\hline $\mathrm{P} / \mathrm{Pb}$ & $69 / 31$ & $82 / 18$ & $96 / 4$ & $74 / 26$ & $89 / 11$ & $92 / 8$ \\
$\mathrm{Mg} / \mathrm{Pb}$ & $64 / 36$ & $80 / 20$ & $91 / 9$ & $78 / 22$ & $85 / 15$ & $96 / 4$ \\
$\mathrm{~K} / \mathrm{Pb}$ & $52 / 48$ & $79 / 21$ & $93 / 7$ & $69 / 31$ & $84 / 16$ & $92 / 8$ \\
$\mathrm{Mn} / \mathrm{Pb}$ & $55 / 45$ & $70 / 30$ & $94 / 6$ & $71 / 29$ & $82 / 18$ & $97 / 3$ \\
\hline & & \multicolumn{5}{c}{ Sulfur } \\
$\mathrm{P} / \mathrm{Pb}$ & $84 / 16$ & $86 / 14$ & $90 / 10$ & $85 / 15$ & $86 / 14$ & $89 / 11$ \\
$\mathrm{Mg} / \mathrm{Pb}$ & $89 / 11$ & $94 / 6$ & $96 / 4$ & $88 / 12$ & $95 / 5$ & $96 / 4$ \\
$\mathrm{~K} / \mathrm{Pb}$ & $76 / 24$ & $81 / 19$ & $88 / 12$ & $77 / 23$ & $82 / 18$ & $87 / 13$ \\
$\mathrm{Mn} / \mathrm{Pb}$ & $65 / 35$ & $84 / 16$ & $89 / 11$ & $82 / 18$ & $92 / 8$ & $94 / 6$ \\
\hline
\end{tabular}

*Proportion was calculated as quota (in percent) of the element content of the sum two elements content in the needle dry weight.

15 times. Lead and zinc were used to show that the highest content of mobile forms of polluting elements is registered in upper humus-accumulative soil horizons (Figure 2), this is accounted for by strong fixation of these elements by organic matter.

In mineral horizons lead and sulfur level reduction is found; this is accounted for by flushing regime of soils of city territories. In illuvial texture horizons lead and sulfur concentration increases again at the expense of strong fixation of lead and sulfur ions by illuvial colloids. Soilforming horizons have demonstrated a considerable increase of lead and sulfur content as compared to background values; this confirms active vertical transfer of these elements with filtration waters.

In the city territory there are also found significant changes of soil CEC: level of calcium exchangeable forms in the upper soil horizons increases by $1.4-10$ times as compared to background values, that of magnesium and potassium-by $1.2-2.5$ times, that of sodium - by 1.2 - 6 times. Technogenic deposition of these elements on soil surface and their further vertical migration in soil profile is proven by reliable correlation links ( $r=0.75-0.90, P<0.05, n=32$ ) between the content of these elements in organic litter and in soil genetic horizons: Ad (humus-accumulative), Bt,f (illuvial-texture), C (soil-forming).

The shift of soil solution reaction towards alkalization (near auto-roads), or acidification (in industrial enterprises areas) is also a factor of disturbance of city soils chemical balance. It was found that alteration of city soils acidity induces reacting between lead, cadmium, 
copper, sulfur and exchangeable cations $\left(\mathrm{Ca}^{2+}, \mathrm{Mg}^{2+}, \mathrm{K}^{+}\right.$, $\mathrm{Na}^{+}$) in soil profile (all its horizons). In the soils of background areas such reacting is shown to a lesser degree only in humus and soil-forming horizons.

Comparison of the data on elements-pollutants content in soil horizons with their concentration in city territory trees needles and leaves revealed direct correlation links between these parameters. For example, coefficients of correlation between lead accumulation in soil horizons and its content in plant assimilation organs are fairly high (Table 3). These data allow to assume the process of lead release into soil solution and its active entrance in root system and further to trees assimilation organs from city soil profile.

\section{DISCUSSION}

Many city studies are based on ecological-geochemical analysis of qualitative and quantitative indices of individual components of city environment [2,11-16]. In this respect of particular interest are studies related to functioning and transformation of city environment staple constituents - plants and soil cover in their interaction [17-21]. It is the plants, arboreal ones in particular, and soils are subject to significant emission load, thus in many respects determining further circulation of pollut-

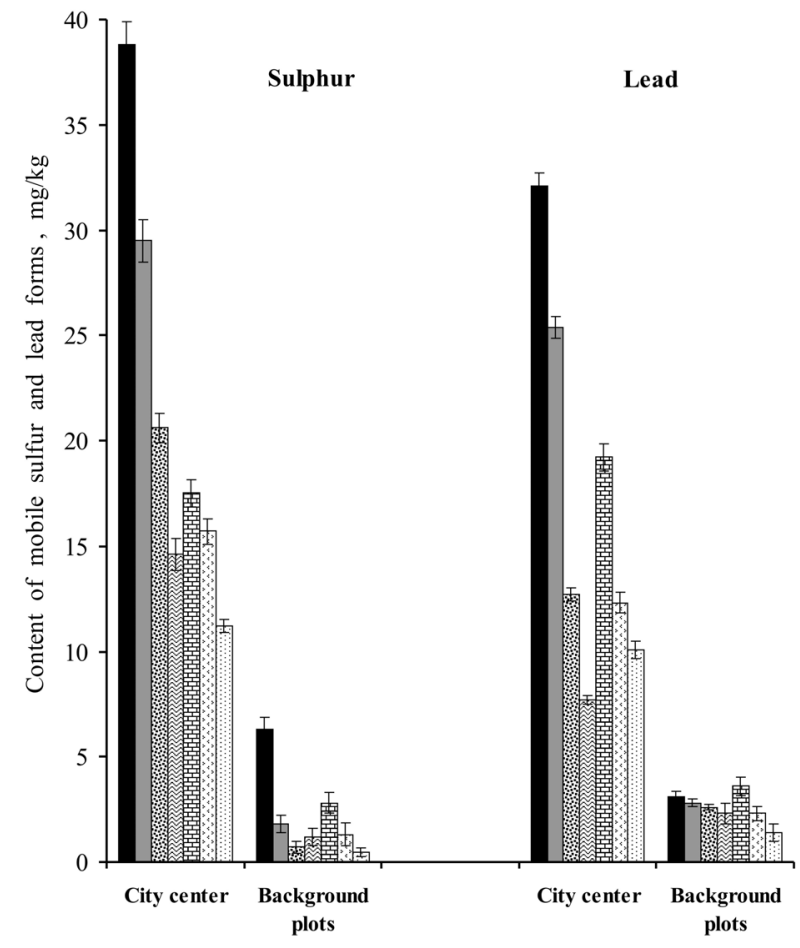

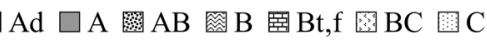

Figure 2. Content mobile forms of sulfur and lead in horizons of city and background soils.
Table 3. Coefficients of correlation between lead content in soil horizons and lead content in needles (leaves) of city trees $(P<$ $0.05, n=32$ ).

\begin{tabular}{|c|c|c|c|c|c|c|c|c|}
\hline \multirow{2}{*}{$\begin{array}{l}\text { Needles } \\
\text { (leaves) of } \\
\text { city trees }\end{array}$} & \multicolumn{8}{|c|}{ Soil horizons } \\
\hline & $\mathrm{O}$ & Ad & A & $\mathrm{AB}$ & $\mathrm{B}(\mathrm{BE})$ & $\mathrm{Bt}, \mathrm{f}$ & $\mathrm{BC}$ & $\mathrm{C}$ \\
\hline $\begin{array}{l}\text { Pine } \\
\text { needles }\end{array}$ & 0.73 & 0.61 & 0.71 & 0.70 & 0.60 & 0.68 & 0.63 & 0.71 \\
\hline $\begin{array}{l}\text { Larch } \\
\text { needles }\end{array}$ & 0.54 & 0.62 & 0.58 & 0.68 & 0.55 & 0.54 & 0.54 & 0.67 \\
\hline $\begin{array}{l}\text { Birch } \\
\text { leaves }\end{array}$ & 0.59 & 0.74 & 0.62 & 0.54 & 0.67 & 0.65 & 0.62 & 0.61 \\
\hline $\begin{array}{l}\text { Poplar } \\
\text { leaves }\end{array}$ & 0.61 & 0.69 & 0.75 & 0.60 & 0.52 & 0.58 & 0.52 & 0.63 \\
\hline
\end{tabular}

ing elements in urban ecosystem.

In our view, special attention should be paid to the choice of parameters, which adequately reflect plant and soil status. To this end, application of biogeochemical parameters is promising, as they reflect close interaction between these components of urban ecosystem, as well as demonstrate the intensity of their transformation under city environment pressure $[22,23]$.

Within the framework of the studies undertaken change of plant and soil status was researched in their intercomnection, which contributed to more adequate assessment of the degree of urban ecosystem disturbance. The results have shown that among a number of anthropogenic factors affecting urbanized territories, technogenic pollution dominates. The study revealed close links between plant parameters and soil properties (on profile-genetic level); biogeochemical redistribution of major polluting elements arriving with atmospheric emissions was investigated; correlation between nutrition elements disbalance and arboreal plants vital status was established. The data acquired prove high significance of soil cover and arboreal plants in redistribution of polluting flows on urbanized territories.

\section{CONCLUSIONS}

On the whole, the results acquired prove that air pollution of city environment provokes active accumulation and migration of elements-pollutants in the system "soilarboreal plants". Inorganic pollutants (heavy metals and sulfur dioxide) were shown to produce an intense negative impact on soil chemical properties and trees nutriation status. In city territory accumulation of elementspollutants in arboreal trees is a significant factor disturbing their growth characteristics. The level of polluting elements in city trees needles and leaves may exceed their background content by 2 to 25 times, thus causing disbalance between nutrient elements and elements-pollutants. The quota of lead and sulfur considerably increases but quota of nitrogen, phosphorus, calcium, mag- 
nesium, potassium, manganese decreases.

Significant content of polluting elements in all genetic soil horizons in the city territory was identified. Their level was found particularly high in humus-accumulative and illuvial texture horizons, where background content is exceeded by 20 times. There were revealed soils CEC deviations caused by the accumulation of polluting elements in soil solution. Reliable correlation links between the content of polluting elements in soil profile horizons and their concentrations in city trees needles (leaves) confirm high ecological significance of "soil-plant" system as absorber of pollutants in the urbanized territory.

These scientific works have been made by the financial support of the Russian Fund of Fundamental Researches, project No. 12-04-31036 mol_a.

\section{REFERENCES}

[1] Kovalsky, V.V. (1974) Geochemical ecology. Publishing House "Nauka", Moscow.

[2] Kasimov, N.S. (2004) Urban ecology. World Scientific, Moscow.

[3] Shergina, O.V. and Mikhailova, T.A. (2007) Condition of trees and soil cover in the parks and forest parks of Irkutsk. Institute of Geography SB RAS, Irkutsk.

[4] State Report (2012) On the state and environmental protection of the Irkutsk region in the 2011 year. Oblmashinform, Irkutsk.

[5] Batuev, A.R., Belov, A.V. and Vorobyev, V.V. (1998) Regional environmental atlas. SB RAS, Novosibirsk.

[6] Lomonosov, I.S., Gapon, A.E., Arsentyeva, A.G. and Makarov, V.N. (1993) Ekogeochemistry cities towns of Eastern Siberia. Permafrost Institute SB RAS, Yakutsk.

[7] Antipov, A.N., Batuev, A.R. and Belov, A.V. (2004) Atlas. Irkutsk region (environmental conditions of development). Institute of Geography SB RAS, Moscow and Irkutsk.

[8] UNEP (1994) Manual on methodologies and criteria for harmonized sampling, assessment, monitoring and analysis of the effects of air pollution on forests. United Nations Environment Programme and Economic Commission for Europe, Hamburg and Prague.

[9] Mikhailova, T.A., Berezhnaya, N.S. and Ignatieva, O.V. (2006) The elemental composition of pine needles and morphological parameters of Scots pine under conditions of technogenic pollution. Institute of Geography SB RAS, Irkutsk.
[10] Vorobyova, G.A. (1999) Classification and taxonomy of soils in the south (development) part of the Irkutsk region: Methodical instructions. Oblmashinform, Irkutsk.

[11] Popov, V.A. and Garanin, V.I. (1987) Ecology of urban territories. Publishing House of Kazan University, Kazan.

[12] Kasimov, N.S. (1995) Ecogeochemistry of urban landscapes. Publishing House of Moscow State University, Moscow.

[13] Bridgman, H., Warner, R. and Dodson, J. (1996) Urban biophysical environments. University Press, Oxford.

[14] Breuste, J., Feldmann, H. and Uhlmann, O. (1998) Urban ecology. Springer-Verlag Berlin Heidelberg, Berlin. doi:10.1007/978-3-642-88583-9

[15] Huinink, J.N.M. (1998) Soil quality requirements for use in urban environments. Soil and Tillage Research, 47, 157-162. doi:10.1016/S0167-1987(98)00087-7

[16] Niemelä, J., Breuste, J.H., Elmqvist, T., Guntenspergen, G., James, P. and McIntyre, N.E. (2011) Urban ecology: Patterns, processes, and applications. Oxford University Press, Oxford.

[17] Jim, C.Y. (1993) Soil compaction as a constraint to tree growth in tropical and subtropical urban habitats. Environmental Conservation, 20, 35-49. doi: 10.1017/S0376892900037206

[18] Pickett, S.T.A., Burch, W.R., Dalton, S.E. and Foresman, T.W. (1997) Integrated urban ecosystem research. Urban Ecosystems, 1, 183-184. doi:10.1023/A:1018579628818

[19] Braun, S. and Flückiger, W. (1998) Soil amendments for plantings of urban trees. Soil and Tillage Research, 49, 201-209. doi:10.1016/S0167-1987(98)00172-X

[20] Ilyin, V.B. and Syso, A.I. (2001) Trace elements and heavy metals in soils and plants of the Novosibirsk region. Publishing House of SB RAS, Novosibirsk.

[21] Pickett, S.T.A., Cadenasso, M.L., Grove, J.M., Nilon, C.H., Pouyat, R.V., Zipperer, W.C. and Costanza, R. (2001) Urban ecological systems: linking terrestrial ecological, physical, and socioeconomic components of metropolitan areas. Annual Review of Ecology and Systematics, 32, 127157. doi:10.1146/annurev.ecolsys.32.081501.114012

[22] Glazovskaya, M.A. (1992) The biogeochemical organization of the environmental space in natural and anthropogenic landscapes as a criterion of their stability. Bulletin of the Russian Academy of Sciences. Series of geographic, 5, 5-12.

[23] Perelman, A.I. (1995) Geochemical landscape as a selforganizing system. Bulletin of the Russian Academy of Sciences. Series of geographic, 4, 10-16. 